\title{
Structuring Land Restitution Remedies for Peace and Stability in Fragile States
}

\author{
Jon D. Unruh \\ McGill University
}

\begin{abstract}
Large-scale dislocation of populations due to land expropriations and armed conflict present significant difficulties for political stability and food security in fragile states. With increased use of mass claims programs by the international community and governments in order to attend to the problem, attention is focusing on what works. While organizing mass claims programs is challenging, the real difficulty is deriving remedies that are realistic, effective, implementable, and that fit the wide variety of circumstances that people, communities and nations find themselves. Although the temptation can be to simply transfer specific remedies from from one country to another, in reality these can be difficult to implement with success in places with different cultures; histories; grievances; aspirations and ethnic, sectarian, religious and class divisions. This paper argues that what is more important is the 'structure' of remedy approaches and how these can be adapted to local and national realities. As well, the necessity of any mass claims program to navigate constraints involving inadequate compensation funds, a lack of alternative lands for reparation, a low capacity administrative environment and a variable willingness to evict current occupants, means that such structures need to be flexible, permutable, and adaptable. This review examines the restitution remedy structures that fit these requirements, and that have been successfully implemented in a variety of land and property mass claims programs.
\end{abstract}

Keywords: Mass claims, land rights, war, expropriation, dislocation.

\section{Introduction}

Forced dislocation of populations from their lands due to wars, poor governance, corruption and discrimination has wide-ranging impact on rural livelihoods, food supply, agricultural economies, and political stability. Often such dislocations are large-scale and long-lasting, with years and even generations intervening between dislocation events and the prospect of returning to lands of origin [1-3] and involve multiple tenure types. In the meantime lands can change hands numerous times, become legally held by others, have significant investments applied, be used in patronage systems, or held by politically powerful individuals or opposed ethnic, sectarian or religious groups [3-5]. Meanwhile the grievances held by the segments of the population that were initially dispossessed usually do not subside, but instead grow, occasionally into political or insurgent movements [1, 6-8]. The problem can ultimately become destabilizing when pent up grievances over loss of lands contributes to the onset of armed conflict, which then causes further dislocation. The fluidity of such instability can then become an opportuni- 
ty to reclaim lands by force that were expropriated in previous decades. For example, the Arab Spring has unleashed a surge of land claims in all affected counties, as populations seek to reclaim land taken from them over decades of patronage-based autocratic and sectarian rule [9]. At the same time dislocation due to armed conflict often lasts longer than the duration of a war, sometimes stretching to generations. The result is that these two sources of dislocation (due to previous expropriation, and due to war), together with the fate of lands over time, means that claims are often about the same lands, particularly given that expropriation and abandonment due to war begets subsequent occupation by others, often followed by a series of good faith transactions. The number of contested land claims that accumulate prior to and after a conflict, then becomes so large and fraught with discord as to have profound negative agricultural productivity and destabilization effects $[6,7,10]$. For this reason large scale land restitution (or mass claims) programs after conflicts are increasingly seen as critical components of peace processes in order to provide stability, re-engage the populace in agriculture and recover national food security $[1,3,7,11-23]$.

While the efforts of governments and the international community to conduct mass claims programs after a war are laudable [16, 24, 25], and the national and international legal basis for doing this is now impressive [14, 18, 19, 26, 27], actually carrying out mass claims programs becomes quite challenging as the claims can number in the thousands or hundreds of thousands, and in the case of Syria will number in the millions. Part of the problem is that claims must be dealt with fairly rapidly so as not to further disaffect claimants, thereby encouraging them to pursue what can be destabilizing alternatives [28, 29]. At the same time the interests of the current occupants of such lands who may have acquired them in good faith from those who expropriated them, must be dealt with so as not to cause further dislocations, injustice and grievance [11].

The techniques for rapid processing of mass claims in land and property have advanced impressively in recent years, particularly with regard to approaches that attend to the priorities of, 1) reducing the volume of claims that such a program has to deal with, 2) determining who has a legitimate claim and who does not, 3) deciding on acceptable forms of evidence and proof for claims, 4) making group decisions for whole categories of claims, and 5) determining a time-frame for events relating to dislocation for which claims can be submitted [12,13, 20,22, 30-32]. Challenging as these priorities are however, the primary difficulty in carrying out mass claims programs are the remedies themselves--the options offered to claimants that will ultimately resolve the claims [7, $12,14,16,33]$. Unless remedies for land restitution are realistic, implementable, acceptable to claimants, and enforceable, then decisions as to eligibility for a remedy will mean very little; with a subsequent loss of faith in the process by claimants. In most cases simply attempting to return lands to their original owners will only be a remedy for a modest subset of claimants. Many land holdings will have been built on and contain residences, factories and office buildings; or will have been converted from small-scale agricultural lands to agribusiness ventures with considerable infrastructure investment $[2,3]$. Other lands will have been destroyed, degraded or rendered otherwise unusable $[34,35]$. Still others will have reverted to alternative forms of ownership not compatible 
with statutory law $[36,37]$. And in other cases the ethnic, tribal, sectarian or religious composition of the area will have changed, precluding a return to previous owners [3-5, 38]. In still other cases evictions in order to return lands to their original owners will itself cause further social unrest $[1,39]$. Considerable innovation is required in order to derive remedies that are able to resolve the multi-faceted dilemmas that land restitution presents. Such remedies must be structured in a way that is flexible, provide multiple options to suit different circumstances, but most importantly they must be realistically implementable.

This review examines what have become some of the more useful remedy structures for mass claims land restitution programs, and looks at how they work and where they have been used. While further innovation is needed, the intention here is to provide examples of how remedies can be structured in ways that are permutable, adaptable to different scenarios, and have worked elsewhere.

\section{Review Method}

While the academic literature on land restitution comprises theory, law, need, and the socio-political repercussions of not engaging in restitution, the literature describing remedy structures that have proven to be realistic and implementable based on their success is scant. In-part this is because the 'successful remedy' topic is closer to the practitioner and policy domain, than it is to the academic research domain. While literature searches were made on Google Scholar, LexisNexis and University legal libraries, what was needed were actual cases of successful implementation of remedy structures. In this regard the primary sources also included material from the International Bureau of the Permanent Court of Arbitration, the Permanent Court of Arbitration, documents pertaining to UN peace operations, the UN Rule of Law program, the UN Habitat International Coalition's Housing and Land Rights Network, law journals, the UN Food and Agriculture Organization's Pinheiro Principles, and the UN International Organization for Migration. References within these sources were checked for additional materials. As well, the grey literature from country level UN restitution programs were gathered by the author during the course of work for the UN on a variety of war-affected land and property rights projects.

\section{Remedies for Mass Claims Land Restitution}

The conventional institutional mechanism for setting up and operating a mass claims program for land and property is usually the 'land commission' [11, 12, 14, 27]. Often derived by decree or as part of a peace accord and comprised of technical legal personel, judges and advisors, a land commission in a post-conflict country is usually recommended and supported by the international community [11, 12, 14, 27]. The land commission determines the criteria for eligibility and the nature of the remedies. More often than not remedies need to comprise much more than simply the return of one's land and the eviction of the current occupant. Permutations and mixes of compensation, alternative lands and opportunity need to be explored, so that a menu of options is structured for use with different categories, circumstances and preferences of claimants. Important in this regard is the understanding that putting together different mixes of 
benefits can get around the very difficult problems of not enough alternative land or compensation funds being available--which is almost always the case [11, 12, 15, 21, 22]. The problems encountered in returning lands or allocating alternative lands to claimants can be particularly difficult. In countries afflicted by expropriations and conflict there are frequently already pronounced information and administrative capacity deficits that makes retaking and reallocating lands extremely complicated. Often there is also a lack of cadastre maps and land surveying services. Databases, if they exist, can be poorly functioning. There can be disorganization and non-cooperation between different government institutions responsible for land allocation, resulting in the same land being allocated to different parties. And indigenous and customary claim and control of lands is usually not recorded. The result is that the government cannot control, allocate, use for compensation, or return lands that it does not know exists and are not mapped or registered. This is a particular problem for rural lands because it can be tempting to simply allocate what appear to be vacant or abandoned lands to claimants as a form of compensation for expropriated lands, so as to avoid the often politically problematic evictions that would need to take place with the return of lands to the original owners. The different remedies that are reviewed here provide examples of the kinds of structures most suited to conducting mass claims where significantly problematic constraints prevail.

\section{Allowing claimants to select from a set of remedies}

A number of mass claims programs have experienced success with having claimants choose which form of remedy they would like to pursue, within a structured framework $[12,13]$. This attends to the wide variety of social, economic and political situations of claimants thereby encouraging resolution of claims. It can also take considerable pressure off of certain remedies that depend on a limited quantity of supply (such as available money in a compensation fund, or alternative lands). The claims commission in Bosnia provided a specific set of remedies that certain categories of claimant could choose from [13]. Once the Bosnian Land and Property Commission recognized the ownership or property right of the claimant, the claimant could then choose the remedy of his/her choice. These choices were limited to, 1) return into possession of the property, 2) compensation for lost property, or 3) simply confirmation of property rights. Each of these choices had a specific structure. The first choice, returning the property, involved the claimant considering just how realistic this return would be, given where and how the claimant lived while dislocated, who was on the property in question, how difficult the legal and bureaucratic process to repossess the land would be, the capacity of the commission to actually evict the current occupant, what the claimant would likely do with the property once returned, and where the property is located and what and/or who was occupying lands next to it. Such considerations are especially significant in the aftermath of a conflict involving ethnic cleansing. In the Bosnia case this option was selected by 54 percent of all claimants. The second option, monetary compensation, was selected by 24 percent of all claimants. With this option, the claimants were told clearly that there were actually no funds for compensation at the time. As well, the Dayton Peace Agreement indicated that compensation need not only be in the form of money, but could also include the issuing of compensation bonds to be used for the future purchase 
of real estate. As well, bonds could be used to facilitate or promote the voluntary exchange of property. Under the third option, the claimant simply requests that the Commission confirms his or her ownership and lawful right to possession of the property, even if someone else was still occupying it. This option provided the claimant the possibility of selecting among a subsequent set of choices; including pursuing legal action against the current occupant, or selling the land to a third party who may have the ability to evict the occupant. This option also acted as a deterrent to the current occupant selling or investing further in the property. For Bosnia, 20 percent of all claimants chose this option [13].

A way to further broaden the variety of possible remedy options that claimants can select from, is to purposefully connect options to the development plans for the country. Claimants could then be prioritized for jobs, benefits, assets, housing, etc., that are associated with development projects, in combination with, or instead of being provided with land or money.

\section{Managing compensation fund payouts}

While compensation funds are very useful in mass claims programs, they almost never are able to fully compensate the many claimants [15]. However there are a variety of ways to structure compensation funds in order to address as many claims as possible. Like many types of remedies in mass claims programs, decisions made for groups of claimants are preferred over making many individual compensation decisions. In this regard the United Nations Compensation Commission (UNCC) for claims related to the 1990 - 1991 Gulf war, derived categories of compensation in order to handle many claims quickly [12]. For the UNCC, different categories of compensation amounts were used to address different types of claims. For example, people who had their individual houses confiscated were given a smaller amount in compensation, compared to those who lost shops, farms, or larger properties. The UNCC derived categories, A, B, C and $\mathrm{D}$ for the different amounts of money to be awarded to different types of claimants. The idea behind this approach was to enable the amount for a claimant to be decided quickly, by deciding to which category a claimant or group of claimants belonged to, instead of attempting to determine what should be the appropriate amounts for each of the thousands of claims separately [12].

The Commission for Real Property Claims of Displaced Persons and Refugees (CRPC) for the mass claims relating to the 1992-1995 war in Bosnia and Herzegovina, used 'compensation bonds' for future purchase of property instead of direct monetary compensation [12]. In this example, the bonds were not money, and could not be exchanged for money though the government. They could however be sold to a third party if the claimant needed cash right away. The compensation bonds were intended to be exchanged for future land or property through the government once (and if) it became available. In this example, no funds were available for cash compensation, such that the issuing of the bonds allowed for a remedy not based on actual cash in a fund. In situations like the land restitution program in southern Yemen [40], where a compensation fund does exist, bonds could be used instead of or in combination with direct cash com- 
pensation for certain categories of claim, so as to allow the compensation fund to attend to more claims. This would produce three possible remedies, bonds, cash, and a mix of the two, thereby allowing for the option of claimant choice to be offered.

The Commission dealing with claims involving the former East Germany also used bonds (redeemable for cash) for compensation, but in this case the amount of the cash the bonds represented was well below full compensation for the property [41]. This meant that the claimant who received such a bond could either redeem it immediately for a smaller amount or would need to wait a number of years before cashing it so that the bond could grow in value. The German government did this as an acknowledgement that it did not have adequate funds available for full compensation to all claimants who desired it. The government also used what it called 'appropriate compensation', which was less than full compensation for confiscated properties, and was offered as an option to claimants who desired immediate cash [41]. One study of several mass claims programs recommends that the amount awarded to individual claimants as compensation should be linked to the total number of claimants that need compensation, together with the total amount available in a compensation fund in order to determine what is 'appropriate compensation' [21]. The Commission dealing with property restitution in Hungary followed this approach and paid compensation in the amount of a small fraction of what full value compensation would be, also due to limited funds [22].

The Ethiopia - Eritrea Claims Commission for claims relating to the 1998 - 2000 war pursued a different approach, authorizing two types of fixed cash compensation linked to the type of evidence presented by the individual claimant or group of claimants [12]. For the first type, there was a fixed-sum compensation of US $\$ 500$ for individuals that were able to provide evidence establishing that the individual belonged to a category of people that had land confiscated. Thus this evidence was one of belonging to the category. The second compensation type was for individuals or groups that possessed enough evidence showing that their individual properties were held previously by them and were confiscated or lost. Thus in this case the evidence was attached to the actual property and not the category, and the amount awarded was US $\$ 1500$.

An additional option for managing compensation when the amount in the fund is not adequate is to adopt rules on the priority of payment, so that the most urgent categories of claimants are attended to first. This can include the most volatile cases, or the most influential, or the most widely known cases, or the claimants most in need of immediate cash compensation. Such a prioritizing can comprise payment of only a percentage of the full award, in order to attend to more cases. After a first round of payments is made, the remaining money in the fund can be used to pay out a second round of payments [12]. This approach can also buy time for additional monies to be located, or for other alternatives to be derived. This was the approach used for the Gulf War Commission, and for the German restitution program [12, 41]. 


\section{Vouchers, credits and shares in companies}

A different approach to get around inadequate compensation funds, is to provide forms of compensation associated with (re)construction. Such alternatives can include, 1) the establishment of a public fund that can issue government bonds, vouchers or individual subsidies that can only be redeemed in the (re)development of lands; 2) government or NGO assistance in finding alternative lands or accessing and developing new lands; 3 ) placement on an official alternative land waiting list; d) the allocation of state land plots to claimants; or, 4) the provision of favorable credits for building materials for infrastructure reconstruction [11]. And again, in some situations a combination of cash compensation and other forms of remedy can be offered in order to make compensation funds last longer [11].

Lebanon has had a fairly positive experience with an alternative to cash compensation after the civil war in that country as the city of Beirut was being rebuilt [42-44]. In this case former owners and occupants of shops, residences and cultivated land in the destroyed and damaged areas of the city and surroundings were given shares in the construction company that rebuilt the downtown areas. The construction company owned the new buildings which were then sold or rented. Because these were new, modern buildings they were of high value, so that as the company gained profitability from the rebuilding venture, the shares increased in value. The holders of the shares were free to sell their shares at any time, but the longer they held onto them the more valuable they became. While this example takes place in largely urban Beirut, it could also be tailored to rural settings involving agribusiness, tourism, farm implement and agricultural input companies. But as well rural inhabitants who lost land and livelihoods could be compensated with shares in the reconstruction of urban areas.

In a review of restitution programs in several Eastern European countries, Kozminski [22] found that shares in either state or privately owned companies were seen to have certain advantages. These included, taking pressure off of a compensation fund, avoiding the politically difficult process of evictions in order to return lands, and avoiding the need to provide alternative lands, which can be scarce, insecure, lack services, or be far from a desired location.

\section{Use of pre-emptive remedies: announcements and injunctions}

Ongoing buying and selling of expropriated lands greatly complicates a restitution process, which generally attempts to stop such transfers until the fate of the lands can be determined. But expropriated lands are particularly problematic in this regard, often experiencing high rates of transfer for reasons connected to their expropriation. Confiscated lands are often subject to multiple transfers involving speculation, consolidation, laundering of funds, attempts to conceal the expropriated nature of the land, and to avoid charges of bad faith transfers while at the same time gaining any restitution compensation due to purported good faith purchasers [45, 46]. In addition, once the existence of a mass claims program becomes known by the public, current occupants of properties can attempt to quickly sell them to others, so as to avoid losing the value of the property entirely. This is different than selling the land to the claimant as part of a 
settlement [13]. In order to discourage this, some commissions have found it worthwhile to make public announcements that indicate the illegality of purchasing lands and properties that have a claim against them [11]. Where such announcements are effective, this can encourage current occupants to deal directly with former owners in order to work out a settlement.

Such announcements can be combined with forms of injunctions that prohibit transfers for specific areas, types of property, certain people, or timeframes [47, 48]. Generally injunctions are one of a number of preventive and protective measures aimed at future acts [49], including continued occupation, sale or exploitation of lands. Injunctions in a mass claims context can be of a wide variety and serve a number of different purposes. They can be short or long-term, permanent or temporary, or apply to one or many people. They can be effectively used to stop or freeze transfers very quickly, while claims processing, decisions and implementation of remedies are underway [47]. Iran has used different forms of injunctions in its property restitution program for claims related to the 1979 Islamic revolution [12].

\section{Managing enforcement}

Enforcement of decisions made by land commissions in support of mass claims is universally a problem [14-16, 33] and requires structures suited to particular circumstances. Enforcement can be difficult as it posits the threat of using force among populations who are usually already very familiar with violence, and requires considerable resources that may not be available. However there are a few structurally innovative approaches. The Housing and Property Claims Commission (HPCC) relating to the 1999 conflict in Kosovo, had as part of its options for remedies, the 'registration of ownership in the appropriate public record' [12] similar to one of the three options offered to claimants in the Bosnia case noted previously. The result was to officially and legally recognize the claimant as the true owner of the property, thereby allowing the claimant to be in a position to legally sell the property; this also makes the current occupant an 'illegal occupant'. While this determination is made without using compensation funds or awarding alternative lands, it can be conflictive however as the illegal occupant can attempt to stay on the property. As in the Bosnia case this would then set up a situation whereby a new buyer will need to deal with the illegal occupant on his/her own terms. However this can also mean that the illegal occupant may either choose to depart or buy the land from the claimant, thus providing compensation that does not come from a compensation fund.

Another approach used by the commissions dealing with mass claims processes relating to the 1990 - 1991 Gulf war, and for the Kosovo conflict, was for the state to withhold a percentage of the salary of the current illegal occupant, with this money either going to the claimant to which compensation is due, or to a general compensation fund [12].

A number of mass claims commissions have used international legal approaches to assist with enforcement. These include commissions dealing with claims from the Bosnia and Herzegovina 1992 - 1995 war; the 1990 - 1991 Gulf war; the Iran 1979 Islamic rev- 
olution; and the 1999 Kosovo conflict [12]. In Yemen's case such a connection was made with the United Nations Security Council's use of UN Chapter 7 to adopt a resolution regarding 'spoilers' in Yemen's transition [50]. While not aimed directly at the land and property mass claims issue, the possibility of being labeled a 'spoiler' in this context would allow the UN resolution to be used as a form of enforcement, or the threat of enforcement. The latter (threat) was the case in Darfur, where the indictment of President Bashir by the International Criminal Court, had an influence among illegal secondary occupants on lands that had been expropriated. This influence pushed some secondary occupants to negotiate with the original owners [51], elaborated further below.

Sometimes working with an international legal NGO can assist in convincing the parties to a claim that voluntary compliance with a land commission's decisions is in their best interest; given that their violation would become known internationally otherwise. Many international NGOs play an important role in national rule of law processes [52]. These organizations can include: the International Legal Foundation, International Alert, Interpeace, The American Bar Association Rule of Law Initiative, among others. The web page of the United Nations Rule of Law Program [52] lists 77 such organizations that can be called upon to assist.

\section{Setting aside contract}

Bad faith transfers are those made with false statements, coercion, while under duress, or through deception. Claims resulting from bad faith transfers can benefit from what is known as 'setting aside contract' [28]. This essentially involves stipulating that all transactions of a certain nature (location, period in time, involving certain groups, etc.) are declared legally null and void, or are to be reviewed. The Commission in Bosnia pursued cancelling contracts for previous land sales if there was a determination that the transfer was made under duress [13]. Such a determination could also be made by a commission deciding that sales were made within a certain time-frame, and in circumstances and in a locale where it was likely that such a coerced or deceptive transfer was made, based on the request of a claimant or not. For Bosnia the claimant was then able to choose between one of the three options noted above--return of property, compensation, or confirmation of rights. A variation of this technique was used in postwar in Iraq, where forced and fraudulent land transfers, or transfers suspected of being so, were frozen en-masse and not allowed to proceed by the Property Registration Department in the Ministry of Justice [53]. More broadly the international community active in postwar scenarios can encourage and even insist on the application of certain legal decrees that freeze all transactions occurring over a specific period of time, or types of transactions in specific areas, retroactively.

In many cases confiscated lands and properties will have been sold multiple times to people who will have paid full market value for them in good faith, and will be unaware that the property in question was previously expropriated. An added complication is that such lands may have been invested in over the years, significantly increasing their value. If a commission's decision is to evict, then the current good faith occupant will usually need to be compensated as well, and the issue of the difference in value between the 
time of confiscation and eviction of the current good faith occupant, will need to be dealt with. The Iraq Commission for the Resolution of Real Property Disputes resulting from the land confiscations that took place from 1968 - 2003, provides that such good faith occupants of confiscated land should be compensated the value of the property at the time the claim is lodged at the commission; and importantly, that the first individual that originally sold the property after the expropriation will need to pay this compensation-even if the Iraqi state was this original seller [11].

\section{Negotiation and settlement between claimants and current occupants}

In many cases actual return to lands and properties by those who were dislocated (or their descendants) will be difficult, impossible, or not desired for a variety of reasons. In Kosovo, Darfur and elsewhere, mediation and negotiation between claimants and current occupants, organized by land commissions or by the parties themselves, resulted in arrangements of selling, leasing or renting the properties in question [11, 54]. In this construct properties can be sold to current occupants by the claimants, or leases or renting arrangements can be made whereby the current occupants periodically make payments to the claimants. Such arrangements can be supported by either the possibility of the current occupant losing the property altogether if negotiations with the claimant are not pursued, or fail--something a land commission can strongly imply. In Kosovo, Bosnia-Herzegovina and Iraq, just the fact that properties were involved in a land claims process led to increased renting, leasing and purchasing arrangements organized by the claimants and current occupants [11]. This was encouraged by public announcements that these arrangements were supported by the authorities and were regarded as one legal way to resolve claims. Such efforts can also be facilitated with information campaigns aimed at current occupants of confiscated lands that there are legal consequences of not complying with restitution decisions and judgements. In addition, if it becomes widely known that at least one influential occupant has either lost land in the restitution process, or has made a rental, leasing or sale arrangement with a claimant, this can encourage other negotiated arrangements.

A number of commissions dealing with mass claims have structured claims processes to specifically promote different forms of arrangements between claimants and occupants. These include the Housing and Property Claims Commission in Kosovo, the commission dealing with claims related to Iran's 1979 Islamic Revolution, and the Eritrea - Ethiopia claims commission [12]. In Kosovo over 40 percent of those making restitution claims resolved their cases through selling, leasing, or renting the property in question with the current occupant [11]. In this example a state organization provided legal assistance to claimants wanting a negotiated solution with current occupants-however an NGO (domestic or international) could also fill this role. In Darfur, the widely publicized return of internally displaced persons to their lands and properties, facilitated by the UN, led to instances of the current occupants negotiating with claimants on their own [54]. Settlements agreed to between claimants and current occupants are useful in order to reduce the total number of claims that a commission has to resolve. In this regard the question can be, how many claims cases, out of the total that have been filed, can possibly be resolved by settlements between the parties? 
What is required in order to facilitate interaction between the claimant and the current occupant, is a way to inform the two parties that a claim has been lodged against the property and that settlement outside the commission is encouraged. In the Iran claims example, the parties to a potential settlement were required to appear for a 'pre-hearing conference' at the Commission, in order to verify the intent of both parties [12]. In the Kosovo example, one of the most important functions of the Housing and Property Directorate was to strongly encourage the settlement of claims between the parties themselves through a variety of agreements. The Directorate was empowered to take whatever steps necessary to facilitate such settlements, and even developed standardized settlement forms for use by the relevant parties, in addition to certifying such agreements once they have been reached, as the Eritrea - Ethiopia Commission also did [12]. For Kosovo, claims which are not successfully resolved through such agreements or mediation were only then referred to the Commission for a decision [12].

The case of Cyprus considers what form of interaction may take place between claimants and current occupants who have built on, or otherwise improved the property in question. Where the value of the improvement is greater than the original value of the property at the time of confiscation, and the dispossessed owner is not prepared to pay the current occupant for the improvement, then the owner of the improvement may apply to receive title to the property in exchange for paying the original owner the value of the property at the time when the original owner was first dispossessed [23].

A similar form of interaction between claimants and current occupants is to encourage the parties to engage in simplified alternative dispute resolution processes [55]. Because participation in alternative dispute resolution and compliance with decisions are voluntary, this approach is most appropriate between claimants of similar socio-economic status and influence; and would best apply to boundary disputes, failed contracts about lands and properties, and where the role of an authority exists that both parties respect [55].

\section{Conclusion}

The increasing use of mass claims restitution processes to address the socio-political problems associated with large-scale land dispossession, brings attention to bear on remedy structures that are proven to work. While the technical determination of claims eligibility is challenging, the real difficulty lies in deriving and implementing remedies that are able to effectively resolve claims. Given the myriad of situations and circumstances that claimants, commissions, current occupants, civil society and countries find themselves, this paper argues that what is important is the structure of remedy approaches instead of specific remedies that may work well in any single country. Successfully structured remedies are those that favor flexibility, provide multiple options to claimants, are able to be tailored to local circumstances, and importantly can be combined in ways that enhance this flexibility, optioning and tailoring. At the same time successful structures need to be able to manage insufficient monetary funds for compensation, a lack of adequate alternative lands, a low capacity in land and property adminis- 
tration, and an often low degree of willingness or ability to evict current occupants. The intent of this article is to review the more promising remedy structures and provide examples that have successfully worked in existing mass claims programs.

A final note regarding a focus on structure. While many technology-based approaches for land restitution require that claims databases, trained personnel, coordination, adequate funding and logistics be in-place before eligibility can be determined and remedies offered; in reality claims programs need to be structured so as to begin to operate very quickly in a context of inadequate: funding, trained personel, equipment, logistics, security, institutional cooperation, and even sufficient legal backing. This is because an aggrieved population will not wait very long for remedies to be provided and to experience if they are realistic. If such a population is not convinced fairly quickly that a claims program will be able to deliver, then the alternatives pursued often result in further instability.

\section{References}

1. Fischbach $M$. The peace process and Palestinian refugee claims: addressing claims for property compensation and restitution. Washington, DC: United States Institute of Peace; 2006.

2. Du Plessis J. Slow start on a long journey: Land restitution issues in East Timor, 1999-2001. In: Leckie S, editor. Returning home: housing and property restitution rights of refugees and displaced persons. Ardsley, NY, USA: Transnational Publishers; 2003. p. 143-164.

3. Roodt M. Land restitution in South Africa. In: Leckie S, editor. Returning home: housing and property restitution rights of refugees and displaced persons. Ardsley, NY, USA: Transnational Publishers; 2003. p. 243-274.

4. Rempel T. Housing and property restitution: the Palestinian refugee case. In: Leckie $\mathrm{S}$, editor. Returning home: housing and property restitution rights of refugees and displaced persons. Ardsley, NY, USA: Transnational Publishers; 2003. p. 275-316.

5. Huggins C. Peacekeeping and HLP rights in the Great Lakes Region of Africa: Burundi, Rwanda and DR Congo. In: Leckie S, editor. Housing, land and property rights in post-conflict United Nations and other peace operations: A comparative survey and proposal for reform. Cambridge: Cambridge University Press; 2009. p. 179-219.

6. Moyo S, Yeros P. Reclaiming the land: The resurgence of rural movements in Africa, Asia and Latin America. New York: Zed Books; 2005.

7 . Fay D, James D. The rights and wrongs of land restitution: restoring what was ours. New York: Routledge; 2009. 
8. Bradley M. Forced migration, reconciliation and justice. Montreal and Kingston: McGill-Queen's University Press; 2015.

9 . Schechla, J. Land grabs and the Arab spring: A chronicle of corruption as statecraft. Nairobi: Habitat International Coalition's Housing and Land Rights Network; 2012.

10. Unruh JD. Land policy reform, customary rule of law and the peace process in Sierra Leone. African Journal of Legal Studies 2008;2:94-117.

11. FAO. Handbook on housing and property restitution for refugees and displaced persons: Implementing the Pinheiro Principles. Rome: FAO; 2007.

12. Holtzmann $H$, Kristjansdottir E. International mass claims processes: Legal and practical perspectives - remedies. Oxford, UK: Oxford University Press; 2007.

13. Van Houte H. Mass property claim resolution in a post-war society: The commission for real property claims in Bosnia and Herzegovina. International and Comparative Law Quarterly 1999;48:625-638.

14 . Das $\mathrm{H}$, Van Houtte $\mathrm{H}$. Post-war restoration of property rights under international law, Vol 2, Procedural aspects. Cambridge: Cambridge University Press; 2008.

15 . The International Bureau of the Permanent Court of Arbitration. Redressing injustices through mass claims processes: Innovative responses to unique challenges. Oxford, UK: Oxford University Press; 2006.

16. Leckie S. United Nations peace operations and housing, land and property rights in post-conflict settings: from neglect to tentative embrace. In: Leckie S, editor. Housing, land, and property rights in post-conflict United Nations and other peace operations: A comparative survey and proposal for reform. Cambridge, UK: Cambridge University Press; 2009. p. 3-18.

17. Toal G, Dahlman C. Bosnia remade: Ethnic cleansing and Its reversal. Oxford, UK: Oxford University Press; 2011.

18. Burrows A. The Law of restitution. 2nd ed. London: Butterworths LexisNexis; 2002.

19. Kalmanovitz P. Compensation and land restitution in transitions from war to peace. In: López-Guerra C. Maskivker J. editors. Rationality, democracy, and justice the legacy of Jon Elster. Cambridge, UK: Cambridge University Press; 2015. p. 191-222.

20 . Rosenfeld R. Mass claims in international law. Journal of International Dispute Settlement 2003;4:159-174. 
21. Karrer P. Mass claims proceedings in practice - A few lessons learned. Berkeley Journal of International Law 2005;23:463-473.

22. Kozminski A. Restitution of private property, re-privatization in central and eastern Europe. Communist and Post-Communist Studies 1997;30:95-106.

23. International Organization for Migration. Property restitution and compensation: Practices and experiences of claims programmes. Geneva: UN International Organization for Migration; 2008.

24. Cordial M, Rosandhaug K. The response of the United Nations interim administration mission in Kosovo to address property rights challenges. In: Leckie S, editors. Housing, land, and property rights in post-conflict United Nations and other peace operations: A comparative survey and proposal for reform. Cambridge, UK: Cambridge University Press; 2009. p. 61-102.

25 . Foley C. Housing, land and property restitution in Afghanistan. In: Leckie S, editors. Housing, land, and property rights in post-conflict United Nations and other peace operations: A comparative survey and proposal for reform. Cambridge, UK: Cambridge University Press; 2009. p. 136-178.

26. Leckie S. Housing, land and property restitution rights of refugees and displaced persons: Laws, cases, and materials. Cambridge, UK: Cambridge University Press; 2007.

27. Van Houtte H, Delmartino B, Yi I. Post-war restoration of property rights under international aw, volume I: Institutional features and substantive law. Cambridge, UK: Cambridge University Press; 2008.

28 . Haersolte-van J. Innovations to speed mass claims: New standards of proof. In: Permanent Court of Arbitration, editor. Redressing injustices through mass claims processes. Oxford, UK: Oxford University Press; 2006. p. 13-24.

29. Zimmerman K. A new model for defeating al Qaeda in Yemen. The Critical Threats Project. Available at: http://www.criticalthreats.org/yemen/zimmerman-new-model-for-defeating-al-qaeda-in-yemen-september-10-2015 [Accessed 17 November 2015].

30 . Crook J. Mass claims processes: lessons learned over twenty-five years. In: Permanent Court of Arbitration, editor. Redressing injustices through mass claims processes. Oxford, UK: Oxford University Press; 2006. p. 45.

31. Das $\mathrm{H}$. The concept of mass claims and the specificity of mass claims resolution. In: The International Bureau of the Permanent Court of Arbitration, editor. Redressing injustices through mass claims processes: Innovative responses to unique challenges. Oxford, UK: Oxford University Press; 2006. p. 3-12. 
32. Heiskanen V. Virtue out of necessity: International mass claims and new uses of information technology. In: International Bureau of the Permanent Court of Arbitration, editor. Redressing injustices through mass claims processes: Innovative responses to unique challenges. Oxford, UK: Oxford University Press; 2006. p. 25-40.

33 . Leckie S, editor. Returning home: Housing and property restitution rights of refugees and displaced Ppersons. Ardsley, NY, USA: Transnational Publishers; 2003.

34 . Flint J, de Waal A. Darfur: A short history of a long war. London: Zed Books; 2005. 35. Day S. Regionalism and rebellion in Yemen: A troubled nation. New York: Cambridge University Press; 2012.

36. World Bank. Land tenure for social and economic inclusion in Yemen: Issues and opportunities. Washington DC: World Bank Report No. 54923-YE; 2009.

37. Bartra A, Otero G. Indian peasant movements in Mexico: the struggle for land, autonomy and democracy. In: Moyo S, Yeros P. editors. Reclaiming the land: The resurgence of rural movements in Africa, Asia and Latin America. New York: Zed Books; 2005. p. 389-411.

38 . Dahlman C. Geographies of genocide and ethnic cleansing: The lessons of BosniaHerzegovina. In: Flint C, editor. The geography of war and peacekeeping: From death camps to diplomats. Oxford, UK: Oxford University Press; 2005. p. 174-197.

39. Thomson $\mathrm{N}$. The trouble with Iraq: Lessons from the field on the development of a property restitution systems in 'post' -conflict circumstances. In: Leckie S, editor. Housing, land, and property rights in post-conflict United Nations and other peace operations. Cambridge, UK: Cambridge University Press; 2009. p. 220-259.

40. Hadi M. Republican decree no. 2 of 2013. Government of Yemen, Sana'a, Yemen; 2013.

41 . Jeffress D. Resolving rival claims on East German property upon German unification. Yale Law Journal 2013;527:1991-1992.

42. Humphreys $D$. The reconstruction of the Beirut central district: An urban geography of war and peace. Spaces and Flows: An International Journal of Urban and ExtraUrban Studies 2015;6:1-14.

43. Nagel CR. Reconstructing space, re-creating memory: sectarian politics and urban development in post-war Beirut. Political Geography 2002;21:717-25. 
44 . Ragab TS. The crisis of cultural identity in rehabilitating historic Beirut-downtown. Cities 2011;28:107-14.

45. Posada A. Guerreros y campesinos: El despojo de la tierra en Colombia. Bogota: Groupo Editorial Norma; 2009.

46. Sanchez G. La tierra en disputa: Memorias de despojo y resistencia campesina en la costa Caribe (1960-2010). Bogota: Grupo de Memoria Historica; 2010.

47 . Black H. Black's law dictionary. 6th ed. St Paul, USA: West Publishing; 1991.

48. Laycock D. The scope and significance of restitution. Texas Law Review 1989;67:1277.

49. Unruh J. Pre-emptive and advanced techniques for war-torn land and property rights reacquisition. Land Use Policy 2014;38:111-122.

50. Naharnet. GCC urges U.N. Chapter 7 resolution in Yemen. Naharnet Newsdesk 14 February Accessed on 25 Nov 2015 http://www.naharnet.com/stories/en/167496

51. Abdul-Jalil MA, Unruh JD. Land rights under stress in Darfur: A volatile dynamic of the conflict. War and Society 2013;32:156-181.

52. UN Rule of Law (UNRL). Non governmental organizations. UN Rule of Law Unit. http://www.unrol.org/article.aspx?article_id=23 [Accessed on 24 Nov 2015]

53. Isser D, Van der Auweraert P.. Land, property, and the challenge of return for Iraq's displaced. Washington, D.C: US Institute of Peace Special Report; 2009.

54 . Unruh JD. Land and legality in the Darfur conflict. African Security 2012;5:105-128.

55 . Lieberman JK, Henry JF. Lessons from the alternative dispute resolution movement. Chicago: The University of Chicago Law Review 1986;53:424-439. 